University of Windsor

Scholarship at UWindsor

2008

\title{
The Effect of Globalization and Legal Environment on Voluntary Disclosure
}

Kimberley A. Webb

Steven Cahan

University of Auckland Business School

Jerry Sun

University of Windsor

Follow this and additional works at: https://scholar.uwindsor.ca/odettepub

Part of the Business Commons

\section{Recommended Citation}

Webb, Kimberley A.; Cahan, Steven; and Sun, Jerry. (2008). The Effect of Globalization and Legal Environment on Voluntary Disclosure. International journal of accounting, 43 (3), 219-245.

https://scholar.uwindsor.ca/odettepub/36

This Article is brought to you for free and open access by the Odette School of Business at Scholarship at UWindsor. It has been accepted for inclusion in Odette School of Business Publications by an authorized administrator of Scholarship at UWindsor. For more information, please contact scholarship@uwindsor.ca. 


\title{
The Effect of Globalization and Legal Environment on Voluntary Disclosure
}

\author{
Abstract \\ We examine how interactions with foreign capital, product, and labor markets affect \\ the disclosure practices of non-U.S. multinational firms. Drawing on literature related to \\ multinationals, country-level legal institutions, and accounting disclosures, we expect that the \\ relation between globalization and voluntary disclosure will be conditioned on the legal \\ environment in a firm's home country. Specifically, while firms from strong legal \\ environment countries (e.g., common law countries) already face pressure for good \\ disclosure, globalization can increase the benefits associated with good disclosure for firms \\ from weak legal environments (e.g., civil law countries). We use a self-constructed \\ voluntary disclosure index and hand-collected disclosure and foreign activity data for 643 \\ non-U.S. firms from 30 countries. We find a significant interaction between globalization \\ and legal environment. This indicates that for the same level of globalization, there is more \\ voluntary disclosure for firms based in weak legal environments. Our results suggest that \\ globalization is an important variable that has been overlooked in much of the previous \\ cross-country research.
}

Kimberly Webb, Steven F. Cahan, and Jerry Sun. 2008. The International Journal of Accounting, 43(3), 219-245. Post-print 


\section{Introduction}

There is an expanding literature that examines whether a country's legal and judicial institutions affect disclosures and other accounting properties across countries (e.g., Ball, Kothari, \& Robin, 2000; Jaggi \& Low, 2000; Hung, 2001, Ball, Robin, \& Wu, 2003; Hope, 2003a, 2003b; Bushman, Piotroski, \& Smith, 2004; Bushman \& Piotroski, 2006). However, for the most part, these studies do not consider the role of globalization, i.e., they ignore the fact that many firms operate and raise funds in multiple countries. Thus, as firms and markets become increasingly global, there is a need to better understand how globalization impacts on the fundamental effects of legal environments. For example, one important question is whether globalization will accelerate convergence of corporate governance systems of firms around the world (e.g., Hansmann \& Kraakman, 2001).

In this paper, we examine how a firm's voluntary disclosures are affected by its degree of international diversification and by the legal environment in its home country. We argue that while voluntary disclosures should increase with globalization, the effect will be larger for firms based in countries with weak legal environments than for firms based in countries with strong legal environments. That is, we expect that the former will provide more disclosures as a result of their weak legal and judicial institutions at home. Using a sample of 643 non-U.S. firms from 30 countries, a self-constructed index of voluntary disclosure, and hand-collected disclosure and foreign activity data, we find evidence that is consistent with our expectations - in particular, we find a significant interaction between globalization and legal environment. Specifically, the effect of globalization on voluntary disclosures is larger for firms from civil law or low investor protection countries. 
To our knowledge, we are the first to examine the interaction between globalization and legal environment. In doing so, our study contributes to several areas of research. First, we contribute to the on-going debate on whether globalization will drive firms to adopt the same corporate governance systems (e.g., Hansmann \& Kraakman, 2001) or whether corporate governance systems are path dependent and are unlikely to change even as globalization occurs (e.g., Bebchuk \& Roe, 1999). We find that firms from weak investor protection countries that adopt a globalization strategy increase voluntary disclosures the most. This suggests that globalization drives convergence by improving the governance of firms that are not supported by strong legal and judicial institutions at home.

Second, we contribute to an emerging line of research that examines the accounting consequences of foreign firms interacting with U.S. markets. For example, Lang, Raedy, and Yetman (2003) find that non-U.S. firms that are cross-listed in the U.S. have earnings properties that are more like U.S. firms compared to other firms in their home countries, Bradshaw, Bushee, and Miller (2004) find a positive relation between U.S. GAAP conformity of non-U.S. firms and ownership by U.S. institutions, and Khanna, Palepu, and Srinivasan (2004) find that non-U.S. firms are more likely to use U.S. disclosure practices as involvement with U.S. markets increases. Since we do not limit our tests to interactions with U.S. markets, we provide more general evidence on the effects of interacting with foreign markets.

Third, we add to the growing literature that uses country-level institutional features, such as legal origin or investor protection, to explain cross-country differences in accounting properties. For example, Jaggi and Low (2000), Hope (2003b), Francis, Khurana, and Pereira (2005) find that country-level institutional factors matter in explaining disclosure 
levels. Further, Leuz, Nanda and Wysocki (2003) find that earnings management is related to a country's investor protection. Ball et al. (2000) find that the accounting properties of timeliness and conservatism vary between common law and civil law countries. Ball et al. (2003) find that country-level institutional factors can dominate accounting standards, and Hope (2003a) finds that a measure of legal enforcement is related to analysts' forecast accuracy. However, none of the prior studies have considered how globalization affects their results. Our results suggest that globalization may be an omitted variable in these tests.

Fourth, we contribute to the voluntary disclosure literature. Most prior international studies have used the CIFAR scores or, more recently, the transparency and disclosure index developed by S\&P. However, as Bushee (2004) suggests, these indexes are not without problems, and he notes that "the biggest payoff to future researchers will likely come to those who construct their own disclosure indexes" (p. 524) and use hand collected data. We use a voluntary disclosure index based on Francis, Nanda, and Olsson (2007) and hand-collect disclosure data for 643 firms from 30 countries. This allows us to provide more powerful tests of firm-specific disclosure incentives and allows us to complement prior studies that use broad-based, externally-developed disclosure indexes. ${ }^{1}$

Fifth, we contribute to the literature on globalization and multinational firms. Most of this research focuses on U.S. multinationals. For example, Duru and Reeb (2002) find that in the U.S. analysts' forecast accuracy is inversely related to globalization. Callen, Hope, and Segal (2005) find that for U.S. multinationals, the variance of unexpected stock returns is related more closely to domestic earnings than foreign earnings. One reason why prior studies have not considered the effects of globalization for non-U.S. firms is that foreign

\footnotetext{
$1 \quad$ See Bushee (2004) for a discussion of the advantages and disadvantages of the different types of disclosure indexes.
} 
activity data for non-U.S. firms are not widely available on databases like Compustat Global. Here, we augment data from Compustat with hand-collected data on foreign activity. Thus, we are able to examine the effects of globalization for a large, diverse sample of non-U.S. firms.

The remainder of the paper is organized as follows. Section 2 develops hypotheses. Section 3 describes the sample, model and variables used in the study. Section 4 provides descriptive statistics and discusses the results of the empirical tests. Section 5 is a conclusion.

\section{Background and hypotheses}

Several recent studies examine interactions with U.S. markets. Lang et al. (2003) examine the accounting properties of non-U.S. firms that are listed in the U.S. Compared to firms that are not cross-listed, they find cross-listed firms are less likely to manage earnings and are more likely to have earnings that are timely and conservative. Their results also indicate that some of the differences arise in the post cross-listing period. Bradshaw et al. (2004) examine whether conformity with U.S. GAAP affects the level of U.S. institutional ownership for non-U.S. firms. They rate U.S. GAAP conformity by examining 13 accounting method choices and find that greater levels (changes) of U.S. GAAP conformity are related to greater U.S. institutional ownership.

Khanna et al. (2004) argue that non-U.S. firms with more involvement in U.S. capital, product, and labor markets will adopt U.S. disclosure practices. They use a variety of firmlevel and country-level variables to proxy for involvement in U.S. markets. ${ }^{2}$ Further, they

\footnotetext{
$2 \quad$ Khanna et al. (2004) use a U.S. listing variable and country-level variables related to U.S. equity investment and U.S. direct investment to measure involvement in U.S. capital markets, firm-level measures of
} 
use S\&P's transparency and disclosure index which is based on a checklist of 98 disclosure items. They argue that higher scores represent more conformity with U.S. disclosure practices, and using a sample of 794 firms from 24 countries, they find positive relations between most of their U.S. market measures and the S\&P disclosure scores. Khanna et al. (2004) is important because it shows that the capital market is not the only market that may affect a multinational firm's disclosure policy. Instead, product market and labor market forces also can exert pressure on firms to increase disclosures even in the absence of capital market forces.

Together, these studies suggest that interactions by foreign firms with capital, product, and labor markets in the U.S. matter. Our intention is to take a broader perspective - we examine the effects of interactions with markets around the world. We argue that firms may disclose more as globalization increases because exposure to the more capital, product, or labor markets increases the demand for better disclosure and better governance. ${ }^{3}$ However, we also argue that this effect will be most pronounced for firms based in weak legal environments since these firms face weak demand for good disclosure at home and because their disclosures are likely to be viewed as less credible. Thus, we examine whether there is an interaction between globalization and legal environment that affects disclosure.

We draw on several streams of literature to explain why expansion into foreign markets can increase the demand for more disclosure. Though these studies focus on capital

U.S. exports and U.S. operations and a country-level measure of U.S. trade to proxy for U.S. product market interactions, and a country-level measure of business travel to the U.S. to represent U.S. labor market involvement.

3 Globalization could also affect disclosure through firm complexity. That is, global firms may disclose more because they have more complex operations or financing arrangements that require greater disclosure. We design our tests to minimize this complexity effect. Specifically, rather than examine disclosures that are specifically about international activity (e.g., geographic segment disclosures), we use a measure of overall disclosure. 
market forces, similar to Khanna et al. (2004), we see these arguments extending to the product and labor markets as well.

Prior literature on the home bias suggests that investors overweight (underweight) their portfolios with firms based in their home (foreign) countries. Merton's (1987) analysis suggests that information costs can create indirect barriers that lead investors to hold stocks they are familiar with, and prior research suggests that the home bias can arise from insufficient or inadequate information about the firm (e.g., Kang \& Stulz, 1997; Ahearne, Griever, \& Warnock, 2004; Bradshaw et al., 2004; Chan, Covrig, \& Ng, 2005). This suggests that expansion into new markets creates information issues.

Further, there is evidence that suggests that investors and analysts have difficulty in interpreting or understanding information about multinational firms. Duru and Reeb (2002) find that analysts' forecast accuracy for U.S. firms is negatively related to their globalization, and they interpret this as evidence that the forecasting task is more complex when foreign operations are more extensive. Thomas (1999) and Callen et al. (2005) find that U.S. investors place less value on foreign earnings relative to domestic earnings. These authors suggest that their results might be due to poor disclosures.

Analytical research (e.g., Grossman \& Hart, 1980; Milgrom, 1981; Verrecchia, 1983) suggests that firms have incentives to improve the information set available to investors because this can reduce information asymmetry, and can increase liquidity and lower the cost of capital. At a practical level, McKinsey (2002) reports that $70 \%$ of global investors rate accounting disclosures as being important when evaluating foreign investments. Also, empirical evidence suggests that better financial reporting and disclosure can help in an international context. For example, Ashbaugh and Pincus (2001) find that analysts' forecast 
accuracy is higher after firms adopt IAS, and Hope (2003a) finds that analysts' forecast accuracy improves when firm-level disclosure increases. Leuz and Verrecchia (2000) find that German firms switching to U.S. GAAP reporting have lower information asymmetry than firms that continue to report under German GAAP, which is a lower disclosure reporting regime.

While this suggests that multinational firms would have incentive to voluntarily disclose more information, firms may have proprietary reasons for not disclosing information (e.g., Dye, 1986). Though they do not consider foreign segment information, Botosan and Stanford (2005) find that, compared to segment disclosures under SFAS 131, some firms used the latitude provided in SFAS 14 to hide information about operations in industries with less competition. They conclude that firms used SFAS 14 to protect profits in these industries from new competition. Similarly, multinational firms may have incentive to withhold or obfuscate information related to their profitable foreign activities.

The preceding arguments are largely couched in terms of capital markets, but the main issue - information asymmetry - also applies to users in the product and labor markets, and as Khanna et al. (2004) suggest, interactions with foreign product and labor markets can also create a demand for information and better disclosure from multinational firms. For example, they argue that customers require financial information to evaluate a foreign firm's long-term viability, and suppliers use financial statements in evaluating a foreign firm's creditworthiness. Likewise, employees and prospective employees can use financial disclosures in assessing employment opportunities with a foreign firm. These arguments are supported by Bowen, DuCharme, and Shores (1995) who argue that implicit contracts can affect firm's accounting choices. These implicit contracts are relational contracts that depend 
on the firm's reputation. Given the unfamiliarity of firms when they enter foreign product or capital markets, multinational firms have incentives to provide additional information in order to establish and maintain a reputation. This can reduce costs associated with these relational contracts in the long-run.

Whether voluntary disclosure is increasing in globalization is an empirical question. ${ }^{4}$ Thus, we examine the following hypothesis:

H1. The level of voluntary disclosure for a firm is positively associated with its level of globalization.

A second, separate strand of literature examines the effects of country-level legal and judicial institutions on disclosures and other accounting properties (e.g., Ball et al., 2000; Jaggi \& Low, 2000; Hope, 2003a, 2003b; Leuz et al., 2003; Bushman, Piotroski, \& Smith, 2004)). This literature builds on La Porta, Lopez-de-Silanes, Shleifer, and Vishny (1997, 1998) who find that common law countries have stronger investor rights. However, a shortcoming of the prior cross-country research is that it largely ignores the role of globalization. These studies implicitly assume that accounting outputs are affected only by the legal environment in a firm's home country. One exception is Khanna et al. (2004), but their results are specific to U.S. markets and they do not consider the more complex issue of how incentives arising from foreign market involvement and the legal environment interact.

Recently, Doidge, Karolyi, and Stulz (2004) argue that firms raising funds in global capital markets have incentives to improve their corporate governance. Further, they suggest that as corporate governance improves, the influence of country-level investor protection diminishes and this change will be more dramatic for firms based in countries with weak

4 Gray, Meek, and Roberts (1995) and Cahan, Rahman, and Perera (2005) provide some evidence on this issue. However, neither of these studies control for legal environment in their tests. 
legal systems. Their view is based on the argument that firms in weak legal environments do not have incentive to improve their corporate governance because the benefits of doing so are small. For example, one of the benefits of improved disclosure is that it can reduce the cost of capital when raising equity. However, in countries with weak legal environments, equity markets are small so firms have limited opportunities to access equity funding. In contrast, in countries with strong legal systems, equity markets are well developed which gives firms in those countries more opportunities to use equity funding and, hence, more incentives to improve corporate governance including disclosure. Global markets give firms access to not only wider financial markets but also to bigger product and labor markets. This is particularly important for firms from weak legal environments because it increases the benefits of good governance and good disclosure. On the other hand, for firms from strong legal environment countries, accessing global markets will have less impact since these firms already have incentives to have good governance because of the pressures they face at home.

Durnev and Kim (2005) make a similar prediction although they focus on external financing (which could include domestic or foreign financing). However, their arguments are also instructive. They contend that external financing needs will cause firms to improve their corporate governance, but they expect this effect will be more pronounced in weak legal environments. They argue that in weak legal regimes, investors have a lack of trust because they believe their rights will not be protected, and this leads to a higher cost of capital. Thus, firms raising external financing have incentives to maintain high quality governance systems in order to gain investors' trust. While their argument is conceptually different from Doidge et al.'s (2004), both views suggest that raising funds in global capital markets can have a bigger effect on the disclosures of firms that originate in weak legal environments. 
Durnev and Kim's (2005) work also provides a link with the implicit contracts that characterize product and labor markets. As discussed, implicit contracts depend on reputation. Prior research establishes that accounting quality is generally lower when legal and judicial institutions are weak. For example, there is evidence that disclosure levels are lower (e.g., Jaggi \& Low, 2000; Hope, 2003b), earnings are more likely to be managed (Leuz et al., 2003), and earnings are less timely and less conservative (Ball et al., 2000) in weak legal environments. Thus, product and labor market participants such as customers, suppliers, and employees are likely to have less faith in the accounting disclosure of firms domiciled in weak legal regimes. Similar to the way that better disclosures can help gain the trust of investors, they may also help gain the trust of product and labor market participants, and increase the value of the firm's implicit contracts.

Neither Doidge et al. (2004) or Durnev and Kim (2004) provide a test of the interaction between globalization and legal environments. Doidge et al.'s (2004) tests are designed to examine the relative contributions of country- and firm-level characteristics in explaining corporate governance. Thus, they do not include an interaction term. Durnev and Kim (2004) examine the interaction between external financing needs and legal environment, but external financing could be financed through domestic or foreign sources. ${ }^{5}$ Further, they do not consider effect of foreign operations at all.

Thus, our main objective is to examine whether there is an interaction between globalization and legal environment that affects voluntary disclosures. Formally, we hypothesize:

\footnotetext{
5 In a somewhat similar test, Francis et al. (2005) examine the possibility of an interaction between their external financing measure and their country-level variables. They do not find a significant interaction effect (to their surprise, see p. 1144).
} 
H2. The effect of globalization on voluntary disclosure is greater for firms based in countries with weak legal environments than for firms based in countries with strong legal environments.

\section{Research design}

\subsection{Voluntary disclosures}

We use a self-constructed measure of voluntary disclosures based on Francis et al. (2007). This is in contrast to other recent cross-country studies that use externally developed measures of total disclosures, e.g., Hope (2003b) who uses CIFAR ratings and Khanna et al. (2004) who use S\&P's transparency and disclosure scores. Though externally developed indexes have the advantage of being objective and comprehensive, they also have disadvantages (e.g., Bushee, 2004; Francis et al., 2007). For example, both indexes capture total disclosures that include both mandatory and voluntary disclosures. Further, externally developed indexes offer lower construct validity since they were not created with a specific research question in mind, and they can restrict the researcher to non-representative samples that may be motivated by commercial interests of the organization that prepared the index. Bushee (2004) argues that using a self-constructed index and hand-collected data is likely to yield bigger payoffs for future researchers who want to examine disclosures internationally. In our case, using a self-constructed index allows us to isolate voluntary disclosures and more closely examine firm-level reporting incentives for a relatively large and diverse sample of international firms.

Francis et al. (2007) develop a voluntary disclosure index for U.S. firms in a study examining the effect of voluntary disclosure on the cost of capital. While they base their 
index on Botosan (1997), they note that their index differs in two important ways. First, they only consider 'disclosure categories and elements which are clearly voluntary in nature' (Francis et al., 2007, 12), and second, they expand Botosan's index to include non-GAAP measures of financial performance (e.g., free cash flow, residual income). Francis et al. (2007) rate their sample firms based on 25 items divided into four categories, i.e., historical results, other financial measures, non-financial measures, and projected information, and examine whether the disclosure scores are related to the firm's cost of capital. However, they find that their results are driven by disclosure scores in two of these categories - other financial measures and non-financial measures. As a result, we use these two categories to measure voluntary disclosures.

We recognize that Francis et al. (2007) developed their index for U.S. firms. We use their index for a sample of non-U.S. firms because our goal is to identify a set of disclosures that is voluntary in all countries and that has economic significance. Since the U.S. is generally seen as having the more rigorous reporting and disclosure standards in the world (e.g., Reese \& Weisbach, 2002), items that are disclosed voluntarily in the U.S. are very likely to be voluntary in other countries as well. ${ }^{6}$ Further, Francis et al. (2007) show that the items that they disclose affect the firm's cost of capital. This indicates that the items they include in their index have economic significance; in other words, these disclosures are not trivial.

\footnotetext{
$6 \quad$ Nonetheless, similar to Francis et al. (2007), we still conduct exhaustive checks to ensure that each disclosure item is actually voluntary in every country in our sample using the following procedure. For every country and for every disclosure item, we conducted three Google searches using the following key words: (1) 'accounting standards [country name] [disclosure item]', (2) 'company disclosure requirements [country name] [disclosure item]', and (3) 'stock exchange listing requirements disclosure [country name] [disclosure item]'. We also conducted two sets of further searches - one for international accounting standards (i.e., 'international accounting standards [disclosure item]') and one for European Union reporting requirements (i.e., 'European Union company reporting requirements [disclosure item]'). We did not identify any instances where one of our disclosure items was required.
} 
We score the 2003 annual reports for our sample firms using an 11 items index that includes three other financial measures and eight non-financial measures. Table 1 lists these items. ${ }^{7}$ Following Francis et al. (2007), we rate each item on a binary scale. If a firm discloses an item, we give it a score of 1 for that item. We refer to these scores as item scores. Thus, a firm's voluntary disclosure score, VDisc, is the sum of the 11 item scores.

\section{Insert Table 1 here}

Additionally, we employ a modified version of Francis et al.'s (2007) rating system.

For each of the 11 items, we also give every firm a quality score based on the extent and richness of their disclosures. We rate the quality of the disclosure for each item as low, medium, or high. ${ }^{8}$ If the disclosure is rated as 'low', it is given an item score of 1 ; if it is rated 'medium', it is given an item score of 2; and if it is rated 'high', it is given an item score of 3 (as before, a zero score is given for non-disclosure). We define $V D i s c Q$ as the sum of the quality scores for each of the 11 disclosure items. Since scoring VDisc $Q$ require some subjectivity, we believe the results for VDiscQ should be interpreted in conjunction with VDisc.

$7 \quad$ Our 11-item index is similar in terms of number of items to other international studies that use self constructed indexes. For example, Hung (2001) uses an 11-item index related to the use of accrual accounting, Ashbaugh and Pincus (2001) use a 12-item index related to differences from IAS, and Bradshaw et al. (2004) use a 13-item index related to U.S. GAAP conformity. The first two are country-level indexes while Bradshaw et al. (2004) is a firm-level index.

8 To expand on our quality categories, low quality (i.e., a score of 1) indicates that the firm disclosed the item but did not provide any additional discussion; medium quality (i.e., a score of 2) indicates that the firm disclosed the item and provided some additional discussion but did not compare their own results to an industrial average or to the results of competitive firms; and high quality (i.e., a score of 3 ) indicates that the firm disclosed the item, provided some additional discussion, and compared their own results to an industrial average or to the results of competitive firms.

To reduce subjectivity, we use the following procedures: 1) For each disclosure item, a pre-defined list of key words is used to search in annual reports. 2) If a disclosure item is found, the evaluater would read a few neighboring paragraphs containing the key words to determine whether $0,1,2$ or 3 should be given. 3 ) In assigning a score, we define 'discussion' to mean that the annual report listed a breakdown of the required disclosure item, or listed or commented on the firm's previous years' figures or changes of the disclosed item. 
As pointed out before, our intention is to measure voluntary disclosures at a broad level. Thus, we are not specifically interested in disclosures about the firm's international activities (e.g., geographic segment information). There are two reasons for this. First, our hypotheses are not about a particular type of disclosure; we predict a firm's overall disclosures will be affected by globalization and legal environment. Second, we want to minimize any supply-side effects. Global firms may disclose more since they have more complex operations or financing arrangements that require greater disclosure. Since our focus is on a market based explanation, we specifically exclude disclosures related to international activity in order to minimize any complexity effect.

\subsection{Test variables}

We measure globalization as a single concept which is consistent with the literature on multinationals (e.g., Duru and Reeb, 2001). While our measure reflects interactions with foreign capital, product, and labor markets, we do not try to measure the effects of each of these markets separately. Instead, we take the view that globalization can involve a variety of interrelated activities (e.g., a firm that operates in Australia may hire locals, have interactions with Australian customers, and raise funds from Australian creditors). Thus, measures of globalization will be highly correlated.

We use a composite measure of globalization that is based on three measures. Based on Duru and Reeb, 2001; we use the foreign sales ratio (FSales) and the number of foreign subsidiaries (FSubs). ${ }^{9}$ Similar to Hope, 2003a; we use the number of foreign exchanges that

9 Duru and Reeb (2001) use the number of geographic segments rather than number of foreign subsidiaries. We use foreign subsidiaries because this reflects not only the extent of foreign operations but how they are organized. Duru and Reeb (2001) also use the foreign asset ratio, but we exclude this since it would have significantly reduced our sample size. Only $72 \%$ of firms in our sample report foreign assets. 
a firm is listed on (FList). We factor analyze the three variables and use the factor scores from the first factor to measure globalization (Global).

We use hand-collected foreign activity data to augment data from Compustat because foreign activity data are available for only a limited number of non-U.S. firms on Compustat and other widely used databases. ${ }^{10}$ Specifically, we hand-collect data on foreign sales and foreign subsidiaries from the annual report, and we identify foreign listings by reviewing members of stock exchanges in each of our 30 countries using information from Datastream. As a result, we are able to examine the effects of globalization for a larger and more diverse sample of non-U.S. firms than prior studies have used.

Lang et al. (2004) point out that there is no single, universally accepted measure of legal environment. For our main tests, we use the most basic measure of legal environment, i.e., legal origin. As La Porta, Lopez-de-Silanes, Shliefer, and Vishny $(1997,1998)$ and subsequent research have shown, legal origin is powerful enough to explain differences in country-level characteristics such as investor protection, financial development, and ownership patterns. We use a binary variable, Legal, that is coded 1 for common law countries and 0 for civil law countries to measure legal origin. In additional tests, we use two alternative measures of legal environment. First, we use a measure of investor protection from Leuz et al. (2003). They identify three levels of investor protection from a cluster analysis based on nine institutional variables from La Porta et al. $(1997,1998) .{ }^{11}$ Second, we use a measure of securities law from Bushman and Piotroski (2006) that is based on measures

$10 \quad$ We are able to obtain some foreign activity data using the geographic segment data provided on the Compustat North America database. This is potentially available only for firms that are cross-listed in the U.S. 11 The nine variables are related to stock market capitalization, number of listed domestic firms relative to the population, number of IPOs relative to the population, ownership concentration, anti-director rights, disclosure, efficiency of judicial system, rule of law, and corruption. 
of private and public enforcement of securities law from La Porta, Lopez-de-Silanes, and Shleifer (2006). ${ }^{12}$ Bushman and Piotroski (2006) use the arithmetic sum of the two indexes and classify countries as having either high or low enforcement.

\subsection{Control variables}

To control for other factors that might affect the level or quality of voluntary disclosures, we include controls for firm size, firm growth, financing needs, firm profitability, analyst following, and innate accrual quality. We include firm size to control for disclosure costs, incentives for private information acquisition, and legal costs (e.g., Lang \& Lundholm, 1993) where firm size is measured using the log of the market value of equity (lnMVE) (market value, $M V E$, is adjusted share price times adjusted shares outstanding from Compustat Global Issue). We control for firm growth using the log of the book to market ratio $(\ln B M)(B M$ is Compustat Global Industrial/Commercial \#146/MVE) (e.g., Bamber \& Cheon, 1998)). Capital intensity (CapInt) (\#76/\#89) and the leverage (Lev) (\#106/\#89) are included to control for financing needs, and we control for firm performance using the return on assets (ROA) (\#32/\#89) (e.g., Bushee \& Leuz, 2005)). Further, following Hope (2003a) and others, we control for analyst following (Analysts) calculated from IBES. Based on prior literature, we expect a positive coefficient for each of these control variables.

In addition, Francis et al. (2007) find a complementary relation between innate information quality and voluntary disclosures using U.S. data. That is, as the fundamental quality of the information improves, managers provide more voluntary disclosure. They

12 La Porta et al.'s (2006) measure of public enforcement is based on four indexes related to supervisor attributes, investigative powers, stop and do orders, and criminal sanctions. Their measure of private enforcement is based on two indexes related to disclosure and burden of proof (the disclosure index used by La Porta et al. (2006) is based on disclosure requirements related to issuing securities and is not a measure of accounting disclosures). 
suggest that since innate accrual quality is a primitive construct of voluntary disclosure, tests that ignore innate accrual quality are likely to be confounded. Further controlling for earnings quality in an international context can be important because prior studies such as Hung (2001) find that accounting quality can differ between countries. Consequently, we also control for innate accrual quality.

We adopt an approach developed by Dechow and Dichev (2002) and McNichols (2002) and estimate the following regression:

$\operatorname{CurAcc}_{\mathrm{t}} / A_{\mathrm{t}}=\alpha+\beta_{1} C F O_{t-1} / A_{t}+\beta_{2} C F O_{t} / A_{t}+\beta_{3} C F O_{t+1} / A_{t}+\beta_{4} \Delta R E V_{t} / A_{t}+\beta_{5} P P E_{t} / A_{t}+\varepsilon$

where CurAcc is total current accruals in year $t$ (change in current assets [Compustat Global Industrial /Commerical\#75] - change in current liabilities [\#104] - change in cash [\#60] + change in short-term debt [\#94]); $A$ is average total assets in year $t$ and $t$-1 (\#89); CFO is cash flow from operations in year $t$, which is net income (\#32) less total accruals (TAC) (change in current assets [\#75] - change in current liabilities [\#104] - change in cash [\#60] + change in short-term debt [\#94] - depreciation [\#11]). $\triangle R E V$ is change in revenues (\#1) in year $t-1$ to year $t$. PPE is gross value of property, plant and equipment (\#77) in year $t^{13}$

We estimate equation (1) on a time-series basis for each firm based on data for the period 1993-2004 which is the maximum number of years available on the Compustat Global database. Because computation of the lagged $C F O$ requires two lag years and because computation of the year-ahead $C F O$ requires one lead year, we use nine years (1995-2003) to estimate equation (1). We take the standard deviation of the residuals for firm $i$ over the nine years as an estimate of total accrual quality $(T A Q)$.

13 Consistent with prior research (e.g., Francis et al., 2005, Kothari et al., 2005), throughout our analyses, we winsorize all distributions to the 1 and 99 percentiles. 
Following Dechow and Dichev (2002) and Francis et al. (2007), we regress TAQ on a series of innate factors, i.e.:

$T A Q=\alpha+\beta_{1}$ Size $+\beta_{2} \sigma C F O+\beta_{3} \sigma$ Sales $+\beta_{4} O p C y c+\beta_{5} N e g E a r n+\varepsilon$

where Size is the log of average total assets (\#89); $\sigma C F O$ is the standard deviation of $C F O$, scaled by total assets; $\sigma$ Sales is the standard deviation of sales revenue (\#1), scaled by total assets; $O p C y c$ is the average of sum of accounts receivable days and inventory days (based on \#1, \#4, \#63, \#66); and NegEarn is the number of years of negative earnings (\#32). We then use the predicted values from equation (2) as estimates of innate accrual quality $(I A Q){ }^{14}$ Since large values of $I A Q$ indicate poorer innate accrual quality, we expect a negative relation between $I A Q$ and $\operatorname{VDisc}(\operatorname{VDisc} Q)$.

\subsection{Model}

We estimate the following regression model to test $\mathrm{H} 1$ and $\mathrm{H} 2$ :

$\operatorname{VDisc}(\operatorname{VDisc} Q)=\alpha+\beta_{1}$ Global $+\beta_{2}$ Legal $+\beta_{3}$ Global $*$ Legal $+\beta_{4} I A Q+\beta_{5} \ln M V E+\beta_{6} \ln B M$

$$
+\beta_{7} \text { CapInt }+\beta_{8} \text { Lev }+\beta_{9} R O A+\beta_{10} \text { Analysts }+\varepsilon
$$

where $\beta_{1}$ and $\beta_{3}$ test $\mathrm{H} 1$ and $\mathrm{H} 2$ respectively. We expect a positive coefficient for $\beta_{1}$ and a negative coefficient for $\beta_{3}$.

\subsection{Sample}

We select our sample in a two-step process. As a first step, we identify all firms on the Compustat Global database that have data for all the variables in our tests except for data

$14 \quad$ Francis et al. (2007) find that the significance of most of their traditional control variables (e.g., firm size, log of the book-to-market ratio) decreases when innate accrual quality is included in a regression model explaining voluntary disclosure. They argue that innate accrual quality subsumes the explanatory power since innate accrual quality is based on similar characteristics. Since not much is known about innate accrual quality in an international context, we include both innate accrual quality and the traditional control variables in our models. 
on foreign sales, foreign subsidiaries, and foreign listings (we collect the bulk of our foreign activity data from other sources, primarily annual reports). We find that 854 firms from 49 countries satisfy this criterion. The data requirement for $I A Q$ is by far the most limiting since it requires 11 years of data. Thus, our sample consists of long-lived, surviving firms. While we acknowledge that this introduces a bias that can reduce the generalizability of our results, it also helps us in two ways: (1) It increases homogeneity in our sample which reduces the possibility of omitted variables (e.g., start-up firms or younger firms may be fundamentally different from our firms), and (2) it increases the likelihood that at least some of our firms will be highly globalized since establishing an international presence takes time.

As a second step, we search the Internet for usable annual reports for the 854 firms. We use the 2003 annual report, but in 39 cases the 2003 report was not available so we use the 2002 (20 firms) or 2004 (19 firms) report instead. Thus, we are able to obtain annual reports for 750 of the initial 854 companies. Of these, 49 were not in English, and these were deleted. ${ }^{15}$ Clearly, this also affects the generalizability of our results. At best, our results can only be extended to companies that report in English. Further, we delete another 58 firms that did not have data on foreign sales available through Compustat Global or through their annual reports. ${ }^{16}$ After deleting the non-English reports and firms without foreign sales data, we have a final sample of 643 firms from 30 countries.

One consideration with hand-collected disclosure data is that because the process is time intensive, sample sizes are often small. For example, Botosan (1997) uses hand-

\footnotetext{
15 Of the 49 non-English reports, 38 were in Japanese, 5 in Portugese, 5 in Spanish, and 1 in French. 16 In the final sample, we have 565 firms with foreign activity data from the annual report and 78 firms with foreign activity data from the Compustat North America database (as pointed out in footnote 12, the Compustat data are potentially available only for firms cross-listed in the U.S.). When we have both annual report and Compustat data, we use the annual report amounts to verify the Compustat amounts. In a few cases where amounts were not the same, we use the annual report amounts in our tests.
} 
collected data for a sample of 122 manufacturing firms, and Guo, Lev, and Zhou (2004) use hand-collected data for a sample of 49 biotech firms. ${ }^{17}$ Our sample size compares favorably with Francis et al. (2007) who with 681 firms have one of the largest samples with handcollected disclosure data.

Further, our sample also compares favorably with recent cross-country studies that use externally developed indexes. For example, Khanna et al. (2004) use a sample of 794 firms from 24 countries, Francis et al. (2005) use 672 firms from 34 countries, and Durnev and Kim (2005) use two samples - one of 494 firms from 24 countries that are included in the Credit Lyonnais Securities Asia governance ratings and another of 573 companies from 16 countries that have S\&P's transparency and disclosure scores. Thus, even though we use hand-collected data, we do not have to compromise on sample size.

\section{Results}

\subsection{Descriptive statistics and preliminary analyses}

Table 2 provides a breakdown of the sample by country. Our sample includes firms from 30 countries, 11 common law countries and 19 civil law countries. While the number of common law countries is less, common law countries are represented by more firms in our sample than civil law countries. Overall, we have 494 firms from common law countries (76.8\% of the sample) and 149 firms from civil law countries (23.2\%). Also, $40.1 \%$ of the sample comes from just two common law countries, i.e., the UK (25\%) and Canada (15.1\%). To address concerns that these countries might be driving our results, we report sensitivity tests with the UK and Canadian firms omitted.

\footnotetext{
17 We recognize that both Botosan (1997) and Guo et al. (2004) collect more extensive data for each firm than we do.
} 


\section{Insert Table 2 about here}

Table 3, panel A provides descriptive statistics for VDisc and VDiscQ. VDisc has a mean of 3.484 and a median of 3 . The minimum is 0 which indicates that none of the 11 disclosure items were disclosed. The maximum is 9 which indicates that nine of the 11 items were provided. Thus, based on our index, generally the level of voluntary disclosure is modest, but some firms disclose at high levels. Further, the mean (median) for our voluntary disclosure quality index, $V D i s c Q$, is 5.961 (5.000). The maximum for $V D i s c Q$ is 17 from a theoretical maximum of 33 (i.e., 11 items times a maximum of 3 per item) which suggests that none of the firms in our sample are achieving both a high quantity and high quality of voluntary disclosures.

\section{Insert Table 3 about here}

Table 3, panels B and $\mathrm{C}$ provide more detail on the composition and distribution of VDisc. Panel B shows the frequency of disclosure by item. The most commonly disclosed items are number of employees (disclosed by $87.6 \%$ of firms), average compensation $(64.2 \%)$, and units sold (47.2\%). The least common are the percentage of items sold that were designed or introduced in the last 3-5 years (3.6\%), residual income (4.5\%), and the cost of capital $(5.8 \%)$. Table 3, panel C contains a breakdown of the sample by VDisc. The largest percentage of firms have disclosure scores of $2(25.8 \%)$, followed by $18.8 \%$ with a score of 3 .

Table 3, panel D provides descriptives for VDisc by country. For common law countries, means for VDisc vary from 1.50-4.80. For civil law countries, means for VDisc vary from 2.00-9.00. The purpose of panel D is to give an indication of the range of VDisc both within and between countries, but it is only illustrative. Even though voluntary 
disclosures appear to be higher in civil law countries, such a conclusion is unwarranted since panel D compares the raw scores without controlling for other firm characteristics that affect disclosures.

Table 3, panel E presents descriptives for the remaining variables. Of particular interest are the globalization variables. The mean (median) for FSale is $0.398(0.302)$ which indicates that, on average, almost $40 \%$ of sales for our sample are foreign sourced. The mean for $F S u b$ is 17.456 foreign subsidiaries, but this is influenced by outliers as the median for FSub is 5. Also, the mean (median) for FList is 1.409 (1). While most firms have at least one foreign listing, FList varies from 0-7 so some firms have numerous foreign listings.

Table 4 contains results of the factor analysis of the three global variables. Table 4 , panel A shows that the three globalization variables are positively correlated with $r$ 's ranging from 0.350 to 0.397 . Table 4, panel B indicates that there is one common component with significant explanatory power (i.e., an eigenvalue exceeding 1), and we use the factor score from this component to represent globalization, Global. Final loadings (Table 4, panel C) show that this factor loads most heavily on FList, but all loadings are similar and exceed 0.723 .

\section{Insert Table 4 about here}

Table 5 provides the pairwise correlations for the independent variables. Based on the Pearson correlations (the Spearman correlations are similar), Legal is negatively and significantly related to Global, lnMVE, and Analysts. This indicates that civil law firms in the sample are more internationally diversified, are larger, and have a larger analyst following than common law firms in the sample. To an extent, this is because the civil law sample contains few firms per country which suggests that civil law firms in the sample will 
be the bigger, more established ones in those countries. On the other hand, Global is positively and significantly correlated with $\operatorname{lnMVE}$, Lev, Analysts, and is negatively and significantly correlated with $\ln B M$ and CapInt. Thus, firms with greater foreign involvement are larger and have more leverage, a larger analyst following, higher growth, and lower capital intensity than firms with less foreign involvement. Also, it is worth noting that firm size is significantly correlated with all of the other independent variables.

\section{Insert Table 5 about here}

\subsection{Regression results}

We use equation (3) to test the validity of the two hypotheses simultaneously. Table 6 presents the main results using two alternative dependent variables, VDisc and VDiscQ. Both models have reasonable explanatory power with $R^{2}$ 's of $20.3 \%$ and $20.9 \%$, respectively. Since the results for the two models are similar, we discuss them simultaneously. In both models, Global is positive and significant at least at the 0.05 level based on a one-tailed test. Consistent with H1, voluntary disclosure is increasing in globalization. This is consistent with the view that foreign involvement creates incentives for firms to improve their disclosures.

Consistent with $\mathrm{H} 2$, we find that the interaction between globalization and legal environment, i.e., Global*Legal, is significant at the 0.01 level and negatively signed. This indicates that for the same level of globalization, there is less (more) voluntary disclosure for firms based in common law (civil law) countries. This supports two non-mutually exclusive views: either globalization increases the benefits of disclosure for firms from weak legal environment countries by exposing them to new markets where disclosure is more highly 
valued or that firms from weak legal environment countries need to provide better governance and more disclosures to overcome concerns about the weak laws and institutions that they face at home.

\section{Insert Table 6 about here}

Based on our coding, the coefficient for Global represents the incremental effect of globalization on voluntary disclosures for civil law based firms. The combined coefficients for Global and Global*Legal represent the incremental effect of disclosure for common law based firms. When VDisc is the dependent variable, the combined coefficient (i.e., $0.307+[-$ 0.402] $=-0.095)$ is not significant $(t=-1.13)$ which indicates that globalization has no effect on voluntary disclosure in common law countries. This is consistent with the view that common law firms already face pressure to disclose at high level. When VDiscQ is the dependent variable, the combined coefficient for common law firms is significant but negative (i.e., $0.560+[-1.073]=-0.613, t=-2.50)$. It is not clear to us why the quality of voluntary disclosures for common law firms might decrease as globalization increases. We suggest this as an area for future research.

We also compute the $F$-statistic to test the joint explanatory power of Global and Global*Legal. The F-statistic is 3.468 for the VDisc model which is significant at the 5\% level (two-tailed). The $F$-statistic is 5.983 for the VDisc $Q$ model which is significant at the $1 \%$ level (two-tailed). Together, this shows that Global and Global*Legal are not redundant variables and that they provide explanatory power that is incremental to Legal and the other control variables.

For the control variables, all are significant and correctly signed except for Legal and $I A Q$. Thus, voluntary disclosure, whether measured based on quantity only (VDisc) or 
quantity and quality (VDiscQ), is positively related to growth, firm size, capital intensity, leverage, ROA, and analyst following. This is consistent with most of the prior research. On the other hand, Legal is not significant in either model. Thus, other things equal, voluntary disclosures do not differ between common and civil law country firms. This is contrary to Jaggi and Low (2000) and Hope (2003b) who both find that disclosures are higher in common law countries. However, both of these studies use the CIFAR ratings which include mandatory and voluntary disclosures so their results may be capturing differences in mandatory disclosures across countries. Including mandatory disclosures in the index is inappropriate because mandatory disclosures and legal origin will be highly correlated since mandatory disclosures reflect accounting standards and common law countries have more rigorous accounting standards. Also, our results are different from Francis et al. (2007) who find that $I A Q$ is more highly related to their voluntary disclosure measure than their control variables which include firm size, growth, analyst following, and ROA. ${ }^{18}$

We consider whether our results are sensitive to the way we measure legal environment. As mentioned above, we use two alternative measures for legal environment, i.e., a measure of investor protection from Leuz et al. (2003) and a measure of securities law enforcement from Bushman and Piotroski (2006). Table 7 provides the results. For Table 7 , panel A, we code investor protection (InvPro) equal to 2 if the firm's home country is in Leuz et al.'s (2003) high investor protection cluster, equal to 1 if the firm's home country is

18 One reason for the difference is that accrual quality may not be a good measure of earnings quality (Wysocki, 2005). Wysocki (2005) argues that the Dechow and Dichev (2002) accrual quality measure, which Francis et al. (2007) adopt, is dominated a negative contemporaneous correlation between cash flows and accruals and that it randomly decomposes accruals. If so, it is possible that Francis et al.'s (2007) results are spurious. Alternatively, it is possible that the problems Wysocki (2005) identifies are intensified when using cross-country data, making IAQ a much noisier measure when used in an international context (Francis et al. (2004) only examine U.S. firms). 
in their medium investor protection cluster, and equal to 0 if the firm's home country is in their low investor protection cluster. The results are similar to our main results. Whether we use VDisc or VDiscQ, Global is positive and significant which supports H1, and Global*InvPro is negative and significant which supports $\mathrm{H} 2 .^{19}$

\section{Insert Table 7 about here}

For Table 7, panel B, we code securities law enforcement (SecLaw) equal to 1 if a firm's home country is listed as a high securities law enforcement country using data provided in Bushman and Piotroski (2006, Appendix 2). Our results are again similar to the main results. Both $\mathrm{H} 1$ and $\mathrm{H} 2$ are support. Combined, the results in Table 7 indicate that our results are robust to different definitions of legal environment.

We also consider the possibility that the legal environment in the firm's host country might matter since, in addition to the home country's legal environment, the legal environment in the host country may have an impact on voluntary disclosures as well. To examine this, we include an additional control variable, Host, which captures the legal environment in the firm's primary host country. Host is equal to 1 if the firm's host country is a common law country and 0 otherwise..

Table 8 contains these results. When VDisc is the dependent variable, Host is not significant. When VDiscQ is the dependent variable, Host is positive and significant at the 0.10 level. Thus, this suggests that while the host country's legal environment does not affect the level of voluntary disclosures, it does have a positive impact on the quality of those disclosures. More importantly, our results for $\mathrm{H} 1$ and $\mathrm{H} 2$ are unchanged when Host is included. Thus, controlling for Host, we continue to find that voluntary disclosures increase

19 We find the coefficient for InvPro has $t$-values that reach statistical significance based on two-tailed tests, but since they are incorrectly signed, they are not significant in our one-tailed tests. 
as the firm becomes more global and that this increase is more pronounced for firms based in civil law countries.

\section{Insert Table 8 about here}

We conduct additional robustness checks. First, we include an additional control variable for a U.S. listing since FList does not differentiate between U.S. and other foreign listings. There is a considerable literature that examines the effects of cross-listing in the U.S. (e.g., Reese \& Weisbach, 2002; Lang et al., 2003; Lang et al., 2003; Doidge, 2004), and Khanna et al. (2004) find that a U.S. listing is positively related to the S\&P's disclosure ratings for their sample of non-U.S. firms. Thus, we examine whether our globalization variable is simply proxying for a U.S. listing effect. Second, to consider whether our results are driven by unspecified industry factors, we estimate equation (3) with fixed industry effects. Third, because financial firms have different disclosures from non-financial firms and because their disclosures are highly regulated, we re-run our tests with the financial firms omitted. Our results for these analyses (untabulated) are qualitatively the same as our main results. Fourth, we noted before that over $40 \%$ of the sample is composed of UK firms (25\%) and Canadian (15.1\%). Thus, it is possible that our results might be driven by country effects involving one or both of these countries. Thus, we estimate models based on two reduced samples, one where we delete the UK firms and one where we delete both the UK and Canadian firms. Again, our results are similar to the prior results so even with $40.1 \%$ of the sample omitted, we continue to find support for $\mathrm{H} 1$ and $\mathrm{H} 2 .{ }^{20}$ Fifth, since our dependent variables are positive by design and are constrained to a specific range, it is possible that the

\footnotetext{
20 We also examine the effect of countries with small representations by re-estimating our models with
} countries with 5 or less firms omitted. Our results are qualitatively unchanged. 
assumption of normality may be violated. If so, our OLS estimates may be inconsistent and inefficient. We find our results (untabulated) are robust when we estimate our main models using tobit.

\section{Conclusion}

This study uses hand-collected data on disclosures and foreign activity for a sample of 643 non-U.S. firms from 30 countries. We find that voluntary disclosures are positively related to the degree of globalization and are negatively related to the interaction between globalization and the legal environment in the firm's home country. Our research suggests that globalization is an important variable that has been largely overlooked by prior crosscountry studies that examine the effects of country-level institutions. This has significant implications for future research since firms are becoming increasingly global and markets are becoming more integrated.

Our results indicate that the effects of globalization are most pronounced for firms from weak legal environments. There are two non-mutually exclusive explanations. First, globalization can increase the benefits of disclosure by exposing firms from weaker legal environments to new markets where disclosure is more highly valued. Second, as firms from these countries globalize, they need to provide better governance and extra disclosure to build trust and enhance their reputation. That is, because users unfamiliar with the firm may have concerns about the weak laws and institutions in the firm's home country and the poorer quality of its financial reporting, firms from weak legal environments have incentives to provide better disclosure to alleviate these concerns as they become more international. 
Our results also contribute to the debate about convergence of corporate governance systems. On one hand, Hansmann and Kraakman (2001) argue that globalization will drive firms to adopt similar corporate governance systems (e.g., Hansmann and Kraakman, 2001). On the other hand, Bebchuk and Roe (1999) argue that corporate governance systems are path dependent and are unlikely to change even as globalization occurs (e.g., Bebchuk \& Roe, 1999). Our results support an intermediate view - globalization can affect corporate governance systems, but mainly for those firms domiciled in weak legal environment countries.

We offer a few caveats. Most notably, our sample is biased toward long-lived surviving firms that report in English. This affects the generalizability of our results. Also, we use a self-constructed voluntary disclosure index. Thus, it is less objective than an externally developed index, and it is harder for other researchers to replicate. Further, because of the labor intensity of collecting the data, we only can provide evidence from one period. As a result, we cannot be sure that our results are not time-specific.

Our research could be extended in several ways. First, our design could be extended to other types of investor focused communications such as media releases or conference calls. Second, using a time-series analysis would help develop a stronger causal link between globalization and voluntary disclosures. Third, if finer proxies can be developed, one could explore the relative effects of capital, product, and labor market involvement on voluntary disclosures. Fourth, and perhaps most important, globalization could be included in other tests that use cross-country differences in legal environment as an explanatory variable. For example, it would be worth examining whether accounting properties such as conservatism are a function of both legal environment and globalization. 


\section{References}

Ahearn, A., W. Griever, \& F. Warnock (2004). Information cost and home bias: An analysis of U.S. holdings of foreign equities. Journal of International Economics, 62, 313-336.

Ashbaugh, H., \& M. Pincus. (2001). Domestic accounting standards, international accounting standards, and the predictability of earnings. Journal of Accounting Research, 39, 417-434.

Ball, R., S. P. Kothari, \& A. Robin. (2000). The effects of international institutional factors on properties of accounting earnings. Journal of Accounting and Economics, 29, 1-51.

Ball, R., A. Robin, \& J. S. Wu. (2003). Incentives versus standards: Properties of accounting income in four East Asian countries." Journal of Accounting and Economics, 36, 235-270.

Bamber, L., \& Y. Cheon. (1998). Discretionary management earnings forecast disclosures: Antecedents and outcomes associated with forecast venue and forecast specificity choices. Journal of Accounting Research, 36, 167-190.

Bebchuk, L., \& M. J. Roe. (1999). A theory of path dependence in corporate ownership and governance. Stanford Law Review, 52, 127-170.

Botosan, C. (1997). Disclosure level and the cost of equity capital. The Accounting Review, 72, 323349.

Botosan, C., \& M. Stanford. (2005). Managers' motives to withhold segment disclosures and the effect of SFAS No. 131 on analysts' information environment. The Accounting Review, 80, 751-771.

Bowen, R., L. DuCharme, \& D. Shores. (1995). Stakeholders' implicit claims and accounting method choice. Journal of Accounting and Economics, 20, 255-295.

Bradshaw, M., B. Bushee, \& G. Miller. (2004). Accounting choice, home bias, and U.S. investment in non-U.S. Firms. Journal of Accounting Research, 42, 795-841.

Bushee, B. (2004). Discussion of Disclosure practices of foreign companies interacting with U.S. markets. Journal of Accounting Research, 42, 509-525.

Bushee, B., \& C. Leuz. (2005). Economic consequences of SEC disclosure regulation: Evidence from the OTC bulletin board. Journal of Accounting and Economics, 39, 233-264.

Bushman, R., \& J. Piotroski. (2006). Financial reporting incentives for conservative accounting: The influences of legal and political institutions. Journal of Accounting and Economics, 42, 107-148.

Bushman, R., J. Piotroski, \& A. Smith. (2004) What determines corporate transparency? Journal of Accounting Research, 42, 207-251.

Callen, J., O.-K. Hope, \& D. Segal. (2005) Domestic and foreign earnings, stock return variability, and the impact of investor sophistication. Journal of Accounting Research, 43, 377-412. 
Cahan, S. F., A. R. Rahman, \& H. Perera. (2005). Global diversification and corporate disclosure. Journal of International Accounting Research, 4, 73-93.

Chan, K., V. Covrig, \& L. Ng. (2005). What determines the domestic bias and foreign bias? Evidence from mutual fund equity allocations worldwide. Journal of Finance, 60, 1495-1534.

Dechow, P., \& I. Dichev. (2002). The quality of accruals and earnings: The role of accrual estimation errors. The Accounting Review, 77, Supplement, 35-59.

Diamond, D. (1981). Optimal release of information by firms. Journal of Finance, 40, 1071-1094.

Doidge, C. (2004). U.S. cross-listings and the private benefits of control: Evidence from dual-class firms. Journal of Financial Economics, 72, 519-553.

Doidge, C., G. Karolyi, \& R. Stulz. (2004). Why do countries matter so much for corporate governance? Working paper 10726, National Bureau of Economic Research.

Durnev, A., \& E. Kim. (2005). To steal or not to steal: Firm attributes, legal environment, and valuation. Journal of Finance, 60, 1461-1493.

Duru, A., \& D. M. Reeb. (2002). International diversification and analysts' forecast accuracy and bias. The Accounting Review, 77, 415-433.

Dye, R. (1986). Proprietary and non-proprietary disclosures. Journal of Business, 59, 331-336.

Francis, J., R. LaFond, P. Olsson, \& K. Schipper. (2005). The market pricing of accruals quality. Journal of Accounting and Economics, 39, 295-327.

Francis, J., D. Nanda, \& P. Olsson. (2007). Voluntary disclosure, information quality, and cost of capital. Journal of Accounting Research, forthcoming.

Francis, J., I. Khurana, \& R. Pereira, 2005. "Disclosure Incentives and Effects of Cost of Capital around the World.” The Accounting Review 80 (2005): 1125-1162.

Gray, S., G. Meek, \& C. Roberts. (1995). International capital market pressures and voluntary annual report disclosure by U.S. and U.K. multinationals. Journal of International Financial Management \& Accounting, 6, 43-68.

Grossman, S., \& O. Hart. (1980). Disclosure laws and takeover bids. Journal of Finance, 35, 323334.

Guo, R.J.,, B. Lev, \& N. Zhou. (2004). Competitive costs of disclosures of biotech IPOs. Journal of Accounting Research, 42, 319-355.

Hansmann, H., \& R. Kraakman. (2001). The end of history for corporate law. Georgetown Law Journal, 89, 439-468.

Hope, O-K. (2003a). Disclosure practices, enforcement of accounting standards, and analysts' forecast accuracy: An international study. Journal of Accounting Research, 41, 235-272. 
Hope, O.-K. (2003b). Firm-level disclosures and the relative roles of culture and legal origin. Journal of International Financial Management and Accounting, 14, 218-248.

Hung, M. (2001). Accounting standards and value relevance of financial statements: An international analysis. Journal of Accounting and Economics, 30, 401-420.

Jaggi, B., \& P. Y. Low. (2000). Impact of culture, market forces, and the legal system on financial disclosures. International Journal of Accounting, 35, 495-519.

Kang, J, \& R. Stulz. (1997). Why is there a home bias? An analysis of foreign portfolio equity ownership in Japan. Journal of Financial Economics, 46, 3-28.

Khanna, T., K. G. Palepu, K.G., \& S. Srinivasan. (2004) Disclosure practices of foreign companies interacting with U.S. markets. Journal of Accounting Research, 42, 475-508.

Kothari, S., A. Leone, \& C. Wasley. (2005). Performance matched discretionary accrual measures. Journal of Accounting and Economics, 39, 163-197.

La Porta, R., F. Lopez-de-Silanes, A., Shleifer, \& R. Vishny. (1997). Legal determinants of external finance. Journal of Finance, 52, 1131-1150.

La Porta, R., F. Lopez-de-Silanes, A., Shleifer, \& R. W. Vishny. (1998) Law and finance. Journal of Political Economy, 106, 1113-1155.

La Porta, R., F. Lopez-de-Silanes, \& A., Shleifer. (2006). What works in securities law? Journal of Finance, 61, 1-32.

Lang, M., \& R. Lundholm. (1993). Cross-sectional determinants of analysts ratings of corporate disclosures. Journal of Accounting Research, 31, 246-271.

Lang, M, J. Raedy, \& M. Yetman. (2003). How representative are firms that are cross-listed in the United States? An analysis of accounting quality. Journal of Accounting Research, 41, 363-396.

Leuz, C., D. Nanda, \& P. D. Wysocki. (2003). Earnings management and investor protection: An international comparison. Journal of Financial Economics, 69, 505-527.

Leuz, C., \& R. Verrecchia. (2000). The economic consequences of increased disclosure. Journal of Accounting Research, 38, Supplement, 91-124.

McKinsey \& Co. (20020. Global Investor Opinion Survey: Key Findings. Retrieved from: http://www.mckinsey.com/clientservice/organizationleadership/service/corpgovernance/pdf/GlobalIn vestorOpinionSurvey2002.pdf.

McNichols, M. (2002). Discussion of The quality of accruals and earnings: The role of accrual estimation errors. The Accounting Review, 77, Supplement, 61-69.

Milgrom, P. (1981). Good news and bad news: Representation theorems and applications. Bell Journal of Economics, 12, 380-391. 
Merton, R. (1987). A simple model of capital market equilibrium with incomplete information. Journal of Finance, 42, 483-510.

Reese, W., \& M. Weisbach. (2002). Protection of minority shareholder interests, cross-listings in the United States, and subsequent equity offerings. Journal of Financial Economics, 66, 65-104.

Thomas, W. (1999) A test of the market's mispricing of domestic and foreign earnings. Journal of Accounting and Economics, 28, 243-267.

Verrechia, R. (1983). Discretionary disclosure. Journal of Accounting and Economics, 5, 365-380.

Wysocki, P. (2005). Assessing earnings and accruals quality: U.S. and international evidence. Working paper, MIT Sloan School of Management. 


\section{Table 1}

Coding scheme used to compute VDISC

1. Other Financial Measures

a. Free cash flow (or cash flow other than those reported in the Statement of Cash Flows)

b. Economic profit, residual income type measure

c. Cost of capital (WACC, hurdle rate, EVA target rate)

2. Non-Financial Measures

a. Number of employees

b. Average compensation per employee

c. Percentage of sales or services designed or introduced in past 3-5 years

d. Market share

e. Units sold (or other output measure, e.g., production, customers serviced)

f. Unit selling price (or other price measure, e.g., hourly rate)

g. Growth in units sold (or growth in other output measure)

h. Growth in investment (expansion plans, number of outlets, etc.)

Based on Francis et al. (2007). 
Table 2

Sample firms by country

\begin{tabular}{|c|c|c|}
\hline Country & Frequency & $\%$ \\
\hline Argentina & 3 & 0.47 \\
\hline Australia & 47 & 7.31 \\
\hline Austria & 1 & 0.16 \\
\hline Belgium & 2 & 0.31 \\
\hline Brazil & 14 & 2.18 \\
\hline Canada§ & 97 & 15.09 \\
\hline Chile & 3 & 0.47 \\
\hline Denmark & 3 & 0.47 \\
\hline Finland & 7 & 1.09 \\
\hline France & 19 & 2.95 \\
\hline Germany & 18 & 2.8 \\
\hline Hong Kong§ & 43 & 6.69 \\
\hline India & 6 & 0.93 \\
\hline Ireland $\S$ & 6 & 0.93 \\
\hline Israel§ & 4 & 0.62 \\
\hline Japan & 37 & 5.75 \\
\hline Korea & 4 & 0.62 \\
\hline Malaysia§ & 56 & 8.71 \\
\hline Mexico & 1 & 0.16 \\
\hline Netherlands & 5 & 0.78 \\
\hline New Zealand§ & 7 & 1.09 \\
\hline Philippines & 4 & 0.62 \\
\hline Singapore§ & 28 & 4.35 \\
\hline Sweden & 4 & 0.62 \\
\hline Thailand§ & 40 & 6.22 \\
\hline Taiwan & 1 & 0.16 \\
\hline South Africa§ & 5 & 0.78 \\
\hline Spain & 1 & 0.16 \\
\hline Switzerland & 16 & 2.49 \\
\hline United Kingdom§ & $\underline{161}$ & 25.04 \\
\hline Total & $\overline{643}$ & 100.00 \\
\hline
\end{tabular}

$\S$ Denotes common law country. Country classifications are based on La Porta, Lopez-deSilanes, Shleifer; and Vishny, 1998). 
Table 3

Descriptive statistics

Panel A. Descriptive statistics for dependent variables

\begin{tabular}{lccccc} 
& Mean & $\begin{array}{c}\text { Standard } \\
\text { deviation }\end{array}$ & Minimum & Median & Maximum \\
\hline VDisc & 3.484 & 1.867 & 0.000 & 3.000 & 9.000 \\
VDiscQ & 5.961 & 3.690 & 0.000 & 5.000 & 17.000
\end{tabular}

Panel B. Frequencies by item for VDisc and VDiscQ

\begin{tabular}{|c|c|c|c|c|c|}
\hline \multirow[b]{2}{*}{ Item } & \multicolumn{2}{|c|}{ VDisc } & \multicolumn{3}{|c|}{ VDiscQ } \\
\hline & $=0$ & $=1$ & $=1$ & $=2$ & $=3$ \\
\hline Free cash flows & 540 & 103 & 33 & 70 & 0 \\
\hline Residual income & 614 & 29 & 6 & 23 & 0 \\
\hline Cost of capital & 606 & 37 & 15 & 22 & 0 \\
\hline Number of employees & 80 & 563 & 184 & 379 & 0 \\
\hline Avg. compensation & 230 & 413 & 244 & 169 & 0 \\
\hline Percentage in last 3-5 years & 620 & 23 & 13 & 9 & 1 \\
\hline Market share & 476 & 167 & 60 & 79 & 28 \\
\hline Units sold & 339 & 304 & 66 & 226 & 12 \\
\hline Unit price & 513 & 130 & 24 & 98 & 8 \\
\hline Sales growth & 413 & 230 & 34 & 190 & 6 \\
\hline Investment growth & 402 & 241 & 16 & 225 & 0 \\
\hline
\end{tabular}


Panel C. Distribution of firms by VDisc score

\begin{tabular}{lrr} 
Item & $\mathrm{N}$ & $\%$ \\
\hline 0 & 27 & $4.2 \%$ \\
1 & 40 & $6.2 \%$ \\
2 & 166 & $25.8 \%$ \\
3 & 121 & $18.8 \%$ \\
4 & 96 & $14.9 \%$ \\
5 & 97 & $15.1 \%$ \\
6 & 56 & $8.7 \%$ \\
7 & 26 & $4.0 \%$ \\
8 & 8 & $1.2 \%$ \\
9 & 6 & $0.9 \%$ \\
10 & 0 & $0.0 \%$ \\
11 & 0 & $0.0 \%$
\end{tabular}

Panel D. Descriptive statistics for VDisc by country

\begin{tabular}{|c|c|c|c|c|c|}
\hline & Mean & $\begin{array}{l}\text { Standard } \\
\text { deviation }\end{array}$ & Minimum & Median & Maximum \\
\hline \multicolumn{6}{|c|}{ Common law countries } \\
\hline Australia & 2.936 & 1.405 & 0.000 & 3.000 & 6.000 \\
\hline Canada & 3.289 & 1.984 & 0.000 & 3.000 & 8.000 \\
\hline Hong Kong & 3.163 & 2.023 & 0.000 & 3.000 & 7.000 \\
\hline Ireland & 3.000 & 1.095 & 2.000 & 3.000 & 5.000 \\
\hline Israel & 1.750 & 0.500 & 1.000 & 2.000 & 2.000 \\
\hline Malaysia & 3.411 & 1.581 & 1.000 & 3.000 & 7.000 \\
\hline New Zealand & 2.857 & 2.734 & 0.000 & 1.000 & 7.000 \\
\hline Singapore & 3.821 & 2.195 & 1.000 & 3.000 & 9.000 \\
\hline South Africa & 4.800 & 1.789 & 2.000 & 6.000 & 6.000 \\
\hline Thailand & 3.550 & 1.894 & 0.000 & 3.000 & 7.000 \\
\hline United Kingdom & 3.379 & 1.427 & 0.000 & 3.000 & 7.000 \\
\hline
\end{tabular}


Civil law countries

\begin{tabular}{|c|c|c|c|c|c|}
\hline Argentina & 5.000 & 1.732 & 3.000 & 6.000 & 6.000 \\
\hline Austria & 9.000 & 0.000 & 9.000 & 9.000 & 9.000 \\
\hline Belgium & 4.500 & 2.121 & 3.000 & 4.500 & 6.000 \\
\hline Brazil & 5.071 & 2.165 & 0.000 & 5.000 & 8.000 \\
\hline Chile & 3.667 & 0.577 & 3.000 & 4.000 & 4.000 \\
\hline Denmark & 4.333 & 0.577 & 4.000 & 4.000 & 5.000 \\
\hline Finland & 3.571 & 2.992 & 0.000 & 2.000 & 9.000 \\
\hline France & 4.263 & 2.104 & 1.000 & 4.000 & 9.000 \\
\hline Germany & 5.278 & 2.244 & 2.000 & 5.000 & 9.000 \\
\hline Indonesia & 3.167 & 1.602 & 2.000 & 2.500 & 6.000 \\
\hline Japan & 2.703 & 1.927 & 0.000 & 2.000 & 8.000 \\
\hline Korea & 2.750 & 2.754 & 0.000 & 2.500 & 6.000 \\
\hline Mexico & 5.000 & 0.000 & 5.000 & 5.000 & 5.000 \\
\hline Netherlands & 4.800 & 1.483 & 3.000 & 5.000 & 7.000 \\
\hline Philippines & 2.500 & 1.732 & 1.000 & 2.500 & 4.000 \\
\hline Spain & 4.000 & 0.000 & 4.000 & 4.000 & 4.000 \\
\hline Sweden & 5.500 & 1.291 & 4.000 & 5.500 & 7.000 \\
\hline Switzerland & 4.250 & 1.807 & 0.000 & 4.500 & 7.000 \\
\hline Taiwan & 2.000 & 0.000 & 2.000 & 2.000 & 2.000 \\
\hline
\end{tabular}

Panel E. Descriptive statistics for other variables

\begin{tabular}{|c|c|c|c|c|c|}
\hline & Mean & $\begin{array}{l}\text { Standard } \\
\text { deviation }\end{array}$ & Minimum & Median & Maximum \\
\hline Legal & 0.770 & 0.421 & & & \\
\hline \multicolumn{6}{|c|}{ Globalization variables } \\
\hline FSale & 0.398 & 0.378 & 0.000 & 0.302 & 1.000 \\
\hline FSub & 17.456 & 34.040 & 0.000 & 5.000 & 218.000 \\
\hline FList & 1.409 & 1.672 & 0.000 & 1.000 & 7.000 \\
\hline \multicolumn{6}{|c|}{ Control variables } \\
\hline$I A Q$ & 0.019 & 0.011 & 0.002 & 0.016 & 0.054 \\
\hline
\end{tabular}




\begin{tabular}{|c|c|c|c|c|c|}
\hline $\ln M V E$ & 6.415 & 2.162 & 1.571 & 6.381 & 13.292 \\
\hline $\ln B M$ & -0.515 & 1.050 & -6.261 & -0.422 & 1.373 \\
\hline CapInt & 0.355 & 0.226 & 0.007 & 0.332 & 0.867 \\
\hline Lev & 0.149 & 0.129 & 0.000 & 0.135 & 0.500 \\
\hline$R O A$ & 0.037 & 0.082 & -0.383 & 0.040 & 0.259 \\
\hline Analysts & 8.238 & 9.813 & 0.000 & 5.000 & 45.000 \\
\hline
\end{tabular}

Panel A provides descriptive statistics for the two alternative dependent variables which are defined as follows:

VDisc $=$ sum of item scores for 11 voluntary disclosure items shown in Table 1 where an item score is 0 for nondisclosure, 1 for disclosure;

$V D i s c Q=$ sum of item quality scores for 11 voluntary disclosure items shown in Table 1 where an item quality score is 0 for nondisclosure, 1 for disclosure of low quality, 2 for disclosure of medium quality, and 3 for disclosure of high quality.

VDisc and VDiscQ are based on the 2003 annual report except in 39 cases where the 2003 report was not available. In these cases, the 2002 (20 firms or 2004 (19 firms) report is used instead.

Panel B provides frequencies for the disclosure items on an item-by-item basis. The ' $=0$ ' column represents the number of firms (out of 643 )

that did not disclose that item. The ' $=1$ ' column represents the number of firms (out of 643) that did disclose that item.

Panel C provides a breakdown of sample firms by VDisc score (defined as above). The maximum score for VDisc is 9 out of a theoretical maximum of 11. No firms in the sample have a score of 10 or 11.

Panel D provides descriptive statistics for VDisc (defined above) for every country in the sample. Panel D is divided into common law countries and civil law countries where country classifications are based on La Porta, Lopez-de-Silanes, Shleifer; and Vishny, 1998).

Panel E provides descriptive statistics for the other individual variables used in the study. The variables are defined as follows:

Legal = 1 , if firm is based in common law country; 0 , if based in civil law country where country classifications are based on La Porta, Lopez-de-Silanes, Shleifer; and Vishny, 1998);

FSale $=$ foreign sales/total sales (hand-collected from annual report or Compustat Global Issue);

FSubs $=$ number of foreign subsidiaries (hand-collected from annual report);

FList $=$ number of foreign stock exchanges that a firm is listed on (from Datastream);

$I A Q=$ innate accrual quality which is estimated as described below;

$\ln M V E=\log$ of market value of equity (adjusted share price $\mathrm{x}$ adjusted shares outstanding, from Compustat Global Issue) at the end of 2003 in U.S. dollars;

$\ln B M=$ ratio of $\log$ of the book value of equity (Compustat Global Industrial/Commercial \#146) to market value of equity at the end

of 2003;

CapInt $=$ net plant, property, and equipment (\#76)/total assets (\#89) at the end of 2003;

Lev = total debt (\#106)/total assets (\#89) at the end of 2003;

$R O A=$ net income (\#32)/total assets (\#89) at the end of 2003;

Analysts $=$ number of analysts following the firm (from IBES) at the end of 2003

We compute $I A Q$ as follows. We first estimate the regression: 
where CurAcc is total current accruals in year $t$ (change in current assets [Compustat Global Industrial/Commerical \#75] - change in current liabilities [\#104] - change in cash [\#60] + change in short-term debt [\#94]); $A$ is average total assets in year $t$ and $t-1$ (\#89); and CFO is cash flow from operations in year $t$ is net income (\#32) less total accruals (TAC) (change in current assets [\#75] - change in current liabilities [\#104] - change in cash [\#60] + change in short-term debt [\#94] - depreciation [\#11]). $\triangle R E V$ is change in revenues (\#1) in year $t-1$ to year $t$. PPE is gross value of property, plant and equipment (\#77) in year $t$. Using data for the period 1995-2003, we estimate the above equation on a timeseries basis for each firm. The standard deviation of the residuals for firm $i$ is used as an estimate of total accrual quality (TAQ). We then regress $T A Q$ on firm size (\#89), CFO scaled by total assets (\#89), standard deviation of sales revenue (\#1), operating cycle (i.e., the sum of accounts receivable days and inventory days [based on \#1, \#4,\#63,\#66]), and the number of years with negative earnings (\#32). We use the predicted values from the second regression as a measure of innate accrual quality $(I A Q)$ where high values of $I A Q$ indicate poor innate accrual quality. 


\section{Table 4}

Results of factor analysis of three global diversification variables

Panel A. Pearson correlation matrix

\begin{tabular}{lccc} 
& FSales & FSubs & FList \\
\cline { 2 - 4 } FSales & 1.000 & & \\
FSubs & 0.378 & 1.000 & \\
FList & 0.350 & 0.397 & 1.000
\end{tabular}

Panel B. Total variance explained

\begin{tabular}{cccc} 
Component & Eigenvalue & \% of variance & Cumulative \% \\
\hline 1 & 1.668 & 55.616 & 55.616 \\
2 & 0.708 & 23.613 & 79.229 \\
3 & 0.623 & 20.771 & 100.000
\end{tabular}

Panel C. Factor loadings for Global

\begin{tabular}{lr} 
Variable & Loading \\
\hline FSales & 0.723 \\
FSubs & 0.739 \\
FList & 0.775
\end{tabular}

Panel A provides Pearson correlations for three measures of globalization, FSales, FSubs, and FList which are defined in Table 3.

Panel B provides results from a factor analysis of the three measures. Three components are extracted with only one component with an eigenvalue in excess of 1. Factor scores for the first factor are used as a composite measure of globalization, and this variable is labelled Global.

Panel C provides the factor loadings for Global. 
Table 5

Pairwise correlations among the independent variables

\begin{tabular}{|c|c|c|c|c|c|c|c|c|c|}
\hline & Legal & Global & $I A Q$ & $\ln B M$ & $\ln M V E$ & CapInt & Lev & $R O A$ & Analysts \\
\hline Legal & & $-0.207 * * *$ & $0.259 *$ & -0.003 & $-0.354 * * *$ & 0.031 & -0.061 & 0.054 & $-0.153 * * *$ \\
\hline Global & $-0.258 * * *$ & & $-0.280 * * *$ & $-0.202 * * *$ & $0.499 * * *$ & $-0.078 * *$ & $0.207 * * *$ & $-0.124 * * *$ & $0.316 * * *$ \\
\hline$I A Q$ & $0.241 * * *$ & $0.265 * * *$ & & $0.151 * * *$ & $-0.694 * * *$ & $-0.164 * * *$ & $-0.189 * * *$ & $-0.273 * * *$ & $-0.474 * * *$ \\
\hline $\ln B M$ & 0.119 & $-0.133 * * *$ & $-0.074 *$ & & $-0.476 * * *$ & 0.010 & -0.040 & $-0.410 * * *$ & $-0.390 * * *$ \\
\hline $\ln M V E$ & $-0.391 * * *$ & $0.505^{* * *}$ & $-0.612 * * *$ & $-0.538 * * *$ & & 0.083 & $0.278^{* * *}$ & $0.200 * * *$ & $0.662 * * *$ \\
\hline CapInt & 0.052 & $-0.118 * * *$ & $-0.164 * * *$ & 0.007 & $0.078 *$ & & $0.218 * * *$ & 0.001 & 0.059 \\
\hline Lev & -0.035 & $0.152 * * *$ & $-0.144 * * *$ & -0.063 & $0.215^{* * *}$ & $0.239 * * *$ & & $-0.223 * * *$ & $0.224 * * *$ \\
\hline$R O A$ & -0.048 & -0.060 & $-0.374 * * *$ & $-0.229 * * *$ & $0.277 * * *$ & 0.041 & $-0.152 * * *$ & & $0.153^{* * *}$ \\
\hline Analysts & $-0.156 * * *$ & $0.362 * * *$ & $-0.361 * * *$ & $-0.210 * * *$ & $0.539 * * *$ & 0.035 & $0.140 * * *$ & $0.155^{* * *}$ & \\
\hline
\end{tabular}

Pearson correlations are presented below the diagonal. Spearman correlations are presented above the diagonal.

$*, * *$, and $* * *$ indicate significance at $10 \%, 5 \%$, and $1 \%$ levels, respectively (two-tailed). 
Table 6

Regression results

\begin{tabular}{|c|c|c|c|c|}
\hline Variables & \multicolumn{2}{|c|}{ VDisc } & \multicolumn{2}{|c|}{ VDiscQ } \\
\hline Intercept & 0.752 & 1.39 & 0.584 & 0.55 \\
\hline H1. Global (+) & 0.307 & $2.33 * * *$ & 0.560 & $2.16^{* * *}$ \\
\hline Legal (+) & 0.055 & 0.31 & -0.277 & -0.79 \\
\hline H2. Global*Legal (-) & -0.402 & $-2.53 * * *$ & -1.073 & $-3.43 * * *$ \\
\hline$I A Q(-)$ & 0.199 & 0.02 & 5.873 & 0.33 \\
\hline $\ln \widetilde{B M}(+)$ & 0.193 & $2.27 * *$ & 0.422 & $2.52 * * *$ \\
\hline $\ln M V E(+)$ & 0.313 & $4.97 * * *$ & 0.605 & $4.89 * * *$ \\
\hline CapInt $(+)$ & 1.015 & $3.27 * * *$ & 2.521 & $4.12 * * *$ \\
\hline $\operatorname{Lev}(+)$ & 1.364 & $2.47 * * *$ & 2.595 & $2.38 * * *$ \\
\hline$R O A(+)$ & 2.092 & $2.23 * *$ & 4.238 & $2.29 * * *$ \\
\hline Analysts (+) & 0.012 & $1.45^{*}$ & 0.032 & $1.98 * *$ \\
\hline$n$ & \multicolumn{2}{|c|}{643} & \multicolumn{2}{|c|}{643} \\
\hline Adjusted $\mathrm{R}^{2}$ & \multicolumn{2}{|c|}{0.203} & \multicolumn{2}{|c|}{0.209} \\
\hline F-statistic & \multicolumn{2}{|c|}{$17.33 * * *$} & \multicolumn{2}{|c|}{$17.98 * * *$} \\
\hline
\end{tabular}

This table provides estimates from the regression of voluntary disclosure on globalization, legal environment, the interaction of globalization and legal environment, and control variables. The results in columns 2 and 3 are based on a model where VDisc is the dependent variable. The results in columns 3 and 4 are based on a model where VDisc $Q$ is the dependent variable. All variables, except Global, are defined in Table 3. Global is defined in Table 4.

$*, * *$, and $* * *$ indicate significance at $10 \%, 5 \%$, and $1 \%$ levels, respectively (one-tailed). 
Table 7

Regression results using alternative measure for legal origin

Panel A. Investor protection

\begin{tabular}{|c|c|c|c|c|}
\hline Variables & \multicolumn{2}{|c|}{ VDisc } & \multicolumn{2}{|c|}{ VDiscQ } \\
\hline Intercept & 1.424 & 2.61 & 2.510 & 2.34 \\
\hline H1. Global (+) & 0.415 & $1.92 * *$ & 1.002 & $2.35 * * *$ \\
\hline $\operatorname{InvPro}(+)$ & -0.182 & -1.65 & -0.866 & -3.98 \\
\hline H2. Global*InvPro (-) & -0.211 & $-1.63^{*}$ & -0.660 & $-2.59 * * *$ \\
\hline$I A Q(-)$ & -0.390 & -0.04 & 2.793 & 0.15 \\
\hline $\ln \widetilde{B M}(+)$ & 0.216 & $2.17 * *$ & 0.503 & $2.56 * * *$ \\
\hline $\ln M V E(+)$ & 0.272 & $4.25 * * *$ & 0.511 & $4.05 * * *$ \\
\hline CapInt $(+)$ & 0.978 & $3.08 * * *$ & 2.503 & $4.00 * * *$ \\
\hline $\operatorname{Lev}(+)$ & 1.088 & $1.92 * *$ & 2.283 & $2.05 * *$ \\
\hline$R O A(+)$ & 2.150 & $2.20 * *$ & 4.002 & $2.07 * *$ \\
\hline Analysts (+) & 0.015 & $1.81 * *$ & 0.042 & $2.52 * * *$ \\
\hline $\mathrm{N}$ & \multirow{3}{*}{\multicolumn{2}{|c|}{$\begin{array}{c}611 \\
0.192 \\
15.53 * * *\end{array}$}} & \multirow{3}{*}{\multicolumn{2}{|c|}{$\begin{array}{c}611 \\
0.207 \\
16.95^{* * * *}\end{array}$}} \\
\hline Adjusted $\mathrm{R}^{2}$ & & & & \\
\hline F-statistic & & & & \\
\hline \multicolumn{5}{|l|}{ Panel B. Securities law } \\
\hline Variables & \multicolumn{2}{|c|}{ VDisc } & \multicolumn{2}{|c|}{ VDiscQ } \\
\hline Intercept & 0.870 & 1.65 & 0.695 & 0.67 \\
\hline H1. Global (+) & 0.309 & $2.19 * *$ & 0.393 & $1.41 *$ \\
\hline SecLaw (+) & -0.050 & -0.28 & -0.367 & -1.04 \\
\hline H2. Global*SecLaw (-) & -0.372 & $-2.27 * *$ & -0.727 & $-2.24 * *$ \\
\hline$I A Q(-)$ & 0.644 & 0.07 & 6.823 & 0.38 \\
\hline $\ln B M(+)$ & 0.202 & $2.39 * * *$ & 0.469 & $2.80 * * *$ \\
\hline $\ln M V E(+)$ & 0.309 & $5.03 * * *$ & 0.616 & $5.07 * * *$ \\
\hline CapInt (+) & 0.969 & $3.13 * * *$ & 2.340 & $3.83 * * *$ \\
\hline
\end{tabular}




\begin{tabular}{|c|c|c|c|c|}
\hline $\operatorname{Lev}(+)$ & 1.335 & $2.41 * * *$ & 2.457 & $2.25^{* *}$ \\
\hline$R O A(+)$ & 2.088 & $2.22 * *$ & 4.259 & $2.29 * * *$ \\
\hline Analysts (+) & 0.014 & $1.72 * *$ & 0.038 & $2.33 * * *$ \\
\hline $\mathrm{n}$ & \multicolumn{2}{|c|}{643} & \multicolumn{2}{|c|}{643} \\
\hline Adjusted $\mathrm{R}^{2}$ & \multicolumn{2}{|c|}{0.202} & \multicolumn{2}{|c|}{0.201} \\
\hline F-statistic & \multicolumn{2}{|c|}{$17.24 * * *$} & \multicolumn{2}{|c|}{$17.15^{* * *}$} \\
\hline
\end{tabular}

Panel A provides estimates from the regression of voluntary disclosure on globalization, legal environment, the interaction of globalization and legal environment, and control variables. The results in columns 2 and 3 are based on a model where VDisc is the dependent variable. The results in columns 3 and 4 are based on a model where VDisc $Q$ is the dependent variable. All variables, except Global and InvPro are defined in Table 3. Global is defined in Table 4. InvPro is based on Leuz et al. (2003) who perform a cluster analysis on nine variables related to investor protection at the country-level. The nine variables are related to stock market capitalization, number of listed domestic firms relative to the population, number of IPOs relative to the population, ownership concentration, anti-director rights, disclosure, efficiency of judicial system, rule of law, and corruption. Leuz, Nanda, and Wysocki, 2003) identify three clusters of investor protection. We code InvPro equal to 2 for firms from countries in their high investor protection cluster, equal to 1 for firms from countries in their medium investor protection cluster, and equal to 0 for firms in their low investor protection cluster.

Panel B provides estimates from the regression of voluntary disclosure on legal environment and control variables. The results in columns 2 and 3 are based on a model where VDisc is the dependent variable. The results in columns 3 and 4 are based on a model where VDiscQ is the dependent variable. All variables, except Global and SecLaw, are defined in Table 3. Global is defined in Table 4. SecLaw is based on Bushman and Piotroski (2006). Their measure is the arithmetic sum of two indexes of securities law enforcement developed by La Porta et al. (2006); one measuring public enforcement and the other measuring private enforcement. La Porta et al. (2006) measure of public enforcement is based on four indexes related to supervisor attributes, investigative powers, stop and do orders, and criminal sanctions. Their measure of private enforcement is based on two indexes related to disclosure and burden of proof. SecLaw is a binary variable that is coded 1 for strong enforcement countries. Our values are from Bushman and Piotroski's (2006) Appendix 2.

$*, * *$, and $* * *$ indicate significance at $10 \%, 5 \%$, and $1 \%$ levels, respectively (one-tailed). 
Table 8

Regression results controlling for legal environment in primary host country

\begin{tabular}{|c|c|c|c|c|}
\hline \multirow{2}{*}{$\begin{array}{l}\text { Variables } \\
\text { Intercept }\end{array}$} & \multicolumn{2}{|c|}{ VDisc } & \multicolumn{2}{|c|}{ VDiscQ } \\
\hline & 0.766 & 1.41 & 0.634 & 0.59 \\
\hline H1. Global (+) & 0.287 & $2.13 * *$ & 0.483 & $1.86^{* *}$ \\
\hline Legal (+) & 0.067 & 0.38 & -0.231 & -0.66 \\
\hline H2. Global*Legal (-) & -0.408 & $-2.56 * * *$ & -1.096 & $-3.50 * * *$ \\
\hline$I A Q(-)$ & -0.313 & 0.03 & 3.999 & 0.23 \\
\hline $\ln B M(+)$ & 0.190 & $2.23 * *$ & 0.411 & $2.45^{* * *}$ \\
\hline $\ln M V E(+)$ & 0.307 & $4.83 * * *$ & 0.583 & $4.67 * * *$ \\
\hline CapInt (+) & 0.991 & $3.17 * * *$ & 2.432 & $3.96^{* * *}$ \\
\hline Lev $(+)$ & 1.333 & $2.40 * * *$ & 2.479 & $2.27 * * *$ \\
\hline$R O A(+)$ & 2.043 & $2.17 * *$ & 4.059 & $2.19 * * *$ \\
\hline Analysts (+) & 0.011 & $1.36^{*}$ & 0.029 & $1.82 * *$ \\
\hline Host $(+)$ & 0.126 & 0.74 & 0.463 & $1.39 *$ \\
\hline $\mathrm{n}$ & \multicolumn{2}{|c|}{643} & \multicolumn{2}{|c|}{643} \\
\hline Adjusted $\mathrm{R}^{2}$ & \multicolumn{2}{|c|}{0.202} & \multicolumn{2}{|c|}{0.210} \\
\hline F-statistic & \multicolumn{2}{|c|}{$15.79 * * *$} & \multicolumn{2}{|c|}{$16.55^{* * *}$} \\
\hline
\end{tabular}

This table provides estimates from the regression of voluntary disclosure on globalization, legal environment, the interaction of globalization and legal environment, and control variables. The results in columns 2 and 3 are based on a model where VDisc is the dependent variable. The results in columns 3 and 4 are based on a model where VDiscQ is the dependent variable. All variables, except Global and Host, are defined in Table 3. Global is defined in Table 4. Host is defined as:

Host $=.1$ if the firm's host country is a common law country and 0 otherwise.

$*, * *$, and $* * *$ indicate significance at $10 \%, 5 \%$, and $1 \%$ levels, respectively (one-tailed). 